\title{
Aquaspirillum autotrophicum, a New Species of Hydrogen- Oxidizing, Facultatively Autotrophic Bacteria
}

\author{
MICHEL ARAGNO $†$ ANI HANS G. SCHLEGEL \\ Institut für Mikrobiologie der Universität Göttingen und Institut für Mikrobiologie der Gesellschaft für \\ Strahlen- und Umweltforschung mbH, Munich, in Göttingen, Federal Republic of Germany
}

A facultatively autotrophic, hydrogen-oxidizing spirillum was isolated from a small eutrophic lake in Switzerland. It is medium-sized $(0.6$ to $0.8 \mu \mathrm{m})$ and possesses bipolar tufts of flagella. The guanine-plus-cytosine content of its deoxyribonucleic acid is 60 to $62 \mathrm{~mol} \%$. Based upon its source, morphology, and biochemical features, the organism belongs to the genus Aquaspirillum Hylemon et al. 1973. Because this organism does not closely resemble any of the previously described medium-sized aquaspirilla, it is proposed here as belonging to a new species, Aquaspirillum autotrophicum. The specific epithet refers to the outstanding property of this organism to grow on hydrogen and carbon dioxide as energy and carbon sources, respectively. The type strain of A. autotrophicum, strain SA 32, was deposited with the Deutsche Sammlung von Mikroorganismen under the number DSM 732.

The facultatively chemolithoautotrophic, hydrogen-oxidizing bacteria were, until recently, placed in the genus Hydrogenomonas Orla-Jensen 1909 . The discovery of "hydrogen" bacteria that clearly belonged to other genera, such as Paracoccus (4), Nocardia (1, 6), Mycobacterium $(10,12)$, or Corynebacterium (2), emphasized the taxonomic heterogeneity of this physiological group of organisms (14). Moreover, Davis et al. (3) showed that there were differences in the flagellation of the species previously placed in the genus Hydrogenomonas. They proposed, therefore, to reject the genus Hydrogenomonas and to place the peritrichous organisms in the genus Alcaligenes and the polarly flagellated species in the genus Pseudomonas.

From the water of a eutrophic lake, we recently isolated two strains of a spirillum able to grow autotrophically in a mineral medium under an atmosphere of $\mathrm{H}_{2}-\mathrm{O}_{2}-\mathrm{CO}_{2}$. This finding strongly confirmed the observation that the hydrogen bacteria are taxonomically diverse. The present report is concerned with the characterization and taxonomy of this spirillum.

\section{MATERLALS AND METHODS}

Bacterial strains. The two spirillar strains of hydrogen bacteria studied, SA 32 and SA 33, were isolated at the Institute of Botany, University of Neuchâtel, Switzerland, by C. Schweizer and M. Aragno from water samples of a small eutrophic lake. Le Loclat, near St. Blaise (canton of Neuchatel). The isolation of these bacteria was as previously described (16): water samples were filtered on membrane filters, and the filters were deposited on mineral agar; incu-

† Present address: Institut de Botanique, Laboratoire de Microbiologie, CH 2000 Neuchâtel 7, Switzerland. bation was under an atmosphere of $60 \% \quad \mathrm{H}_{2}-30 \%$ air- $10 \% \mathrm{CO}_{2}$ at $30^{\circ} \mathrm{C}$. Pure cultures were obtained by repeated subculturing on mineral agar plates incubated under a hydrogen-air-carbon dioxide mixture. Purity of the cultures was determined by plating them on different organic media and by observing them microscopically.

Media. The basal mineral medium used contained: $\mathrm{Na}_{2} \mathrm{HPO}_{4} \cdot 12 \mathrm{H}_{2} \mathrm{O}, 9.0 \mathrm{~g} ; \mathrm{KH}_{2} \mathrm{PO}_{4}, 1.5 \mathrm{~g} ; \mathrm{MgSO}_{4} \cdot 7 \mathrm{H}_{2} \mathrm{O}$ $0.2 \mathrm{~g} ; \mathrm{NH}_{4} \mathrm{Cl}, 1.0 \mathrm{~g}$; ferric-ammonium citrate, $0.005 \mathrm{~g}$; $\mathrm{CaCl}_{2} \cdot 2 \mathrm{H}_{2} \mathrm{O}, 0.01 \mathrm{~g}$; trace-elements solution $\mathrm{SL} 6$ (solution SL 4 of Pfennig und Lippert [13] minus ethylenediaminetetraacetate and iron salt), $3.0 \mathrm{ml}$; doubledistilled water, $1,000 \mathrm{ml}$ (15). The final $\mathrm{pH}$ was about 7.1. For autotrophic growth, $0.05 \%$ (wt/vol) $\mathrm{NaHCO}_{3}$ was added, and, unless otherwise stated, cultures were incubated under $5 \% \mathrm{O}_{2}-10 \% \mathrm{CO}_{2}-85 \% \mathrm{H}_{2}$ at $30^{\circ} \mathrm{C}$. If required, $1.7 \%$ (wt/vol) agar (Difco) was added. Stock cultures were maintained autotrophically on mineral agar slants and were transferred to fresh medium every 2 months.

Methods. The utilization of compounds as sole carbon sources was tested on agar plates as described by Stanier et al. (17); the medium used was the basal mineral medium plus $0.2 \%$ carbohydrate, $0.01 \%$ phenol, or $0.1 \%$ of one of a number of other carbon compounds. The control lacked any carbon source. The utilization of compounds as sole nitrogen sources was tested in the same manner as with the carbon sources; however, the medium used was the basal mineral medium without $\mathrm{NH}_{4} \mathrm{Cl}$ but with $0.1 \%$ (wt/vol) succinate plus $0.1 \%(w t / v o l)$ of the nitrogen compound examined. Cleavage of $p$-hydroxybenzoate was tested by the method of Holding and Collee (7). Other characteristics-cell morphology (with phase microscopy); nitrate reduction; phosphatase and sulfatase production; sulfide from cysteine; catalase, oxidase, and urease production; gelatin, casein, starch, and esculin hydrolysis; indole production; acid formation from carbohydrates; selenite reduction; and 
growth with $3 \% \mathrm{NaCl}, 1 \%$ bile, or $1 \%$ glycine-were studied by the methods of Hylemon et al. (8). Intracellular poly- $\beta$-hydroxybutyrate was recognized by its typical appearance in electron micrographs (A. Walther-Mauruschat et al., in preparation) and confirmed by its solubility in chloroform and insolubility in ether.

The guanine-plus-cytosine $(G+C)$ content of the deoxyribonucleic acid (DNA) was determined by thermal denaturation $\left(T_{m}\right)$ in $0.5 \mathrm{M}$ sodium phosphate buffer plus $25 \%$ (vol/vol) formamide, a modification of the method described by Mandel and Marmur (11). $T_{m}$ values were determined at $270 \mathrm{~nm}$ with a Gilford spectrophotometer 240. DNA hybridization was determined by optically following renaturation $\left(T_{r}\right)$ at $T_{r}$ $=T_{m}-25^{\circ} \mathrm{C}$. The degree of binding was calculated according to the formula of DeLey et al. (5).

Electron microscopy. Negative staining was performed with log-phase cells grown on succinate and with either $2 \%$ uranylacetate or $2 \%$ potassium phosphotungstate as the negative stain. Observations were made with a Phillips EM 301 electron microscope.

Growth. Growth, either autotrophic or heterotrophic, was followed turbidimetrically by measuring the optical density of a suspension at $436 \mathrm{~nm}$, in 1-cm cuvettes, with a Zeiss PL 4 photometer.

\section{RESULTS}

From each of two water samples taken during February 1974 from Lake Le Loclat, one at a 3$m$ depth and the other at a $7-m$ depth, a spirillum was isolated that was able to grow aerobically under a hydrogen-oxygen-carbon dioxide mixture. A description of the two strains, which were nearly identical in their morphological and biochemical features, is presented below.

The cells are curved to helical with a clockwise orientation of the spirals. The dimensions, determined by phase microscopy in 18-h-old PSS broth cultures (8) at $30^{\circ} \mathrm{C}$, are as follows: cell diameter, 0.6 to $0.8 \mu \mathrm{m}$; cell length, 2.0 to 5.0 $\mu \mathrm{m}$; wave length, 3.0 to $4.0 \mu \mathrm{m}$. Longer cells (up to $50 \mu \mathrm{m}$ ) were obtained with late-log-phase cultures in gluconate $(0.2 \%$, wt/vol)-mineral medium. At $\mathrm{pH} 6.5$ and above, the cells were motile by means of one to five flagella at each pole (Fig. 1). The Gram reaction was negative. Coccoid bodies were not observed in 3-week-old PSS broth cultures. Intracellular poly- $\beta$-hydroxybutyrate granules were present. Colonies on succinate-mineral agar were cream-colored, translucent, up to $3 \mathrm{~mm}$ in diameter, circular, and convex.

The growth rate was optimal in succinatemineral medium at $28^{\circ} \mathrm{C}$. There was detectable growth at 10 and $35^{\circ} \mathrm{C}$ but no growth at $37^{\circ} \mathrm{C}$. The $\mathrm{pH}$ for optimum growth was between 5 and 8; however, motility was strongly diminished below $\mathrm{pH}$ 6.5.

The biochemical properties of the two strains are summarized in Table 1.

The results of the utilization by the two strains

TABLE 1. Biochemical characteristics and penicillin susceptibility of the "hydrogen spirillum"

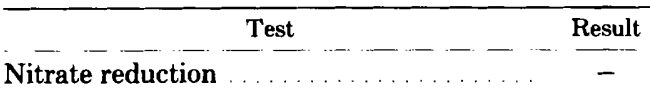

Anaerobic growth with nitrate ........ -

Phosphatase ...........

Sulfatase $\ldots \ldots \ldots \ldots \ldots \ldots \ldots \ldots \ldots$ -

Oxidase ...............

Catalase . . . . . . $\ldots \ldots \ldots \ldots \ldots \ldots \ldots$

Urease

Protocatechuate cleavage in $p$-hydroxybenzoate metabolism

Hydrolysis of gelatin

Hydrolysis of casein

Hydrolysis of starch

Hydrolysis of esculin

Production of water-soluble fluorescent pigment

Indole formation

$\mathrm{H}_{2} \mathrm{~S}$ from cysteine

Acids from carbohydrates

Growth in the presence of $1 \%$ bile salts

Growth in the presence of $1 \%$ glycine

Growth in the presence of $3 \% \mathrm{NaCl}$

Selenite reduction

Minimal inhibitory concn of penicillin $G$ ortho

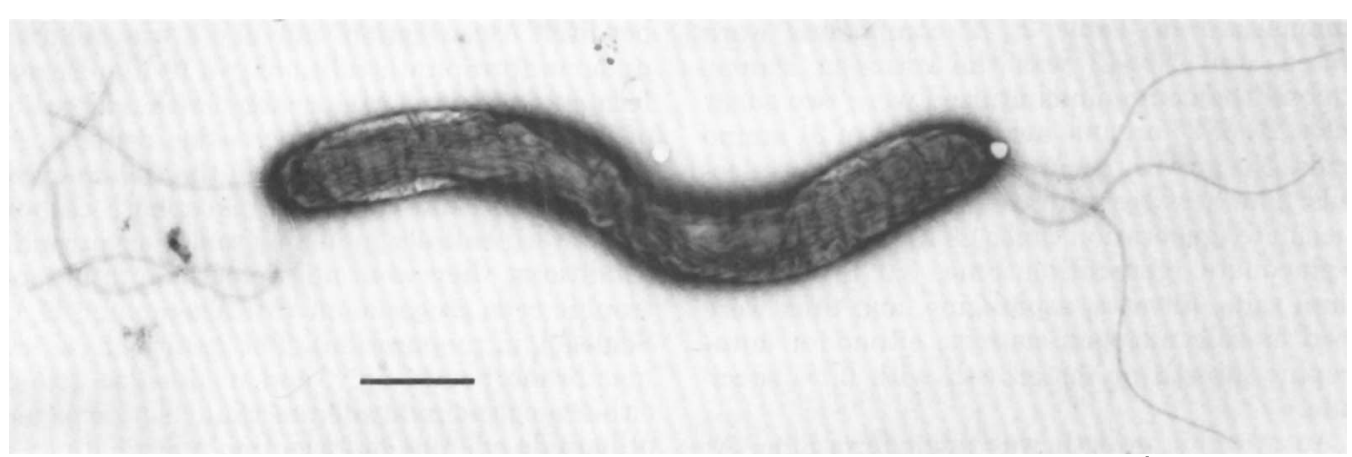

Fig. 1. Electron micrograph of a cell of strain SA 32, negatively stained with uranylacetate. Bar represents $1 \mu m$. 
TABL.E 2. Results of sole carbon source utilization tests with strains $\mathrm{SA} 32$ and $\mathrm{SA33}$, using $\mathrm{NH}_{4} \mathrm{Cl}$ as the nitrogen source

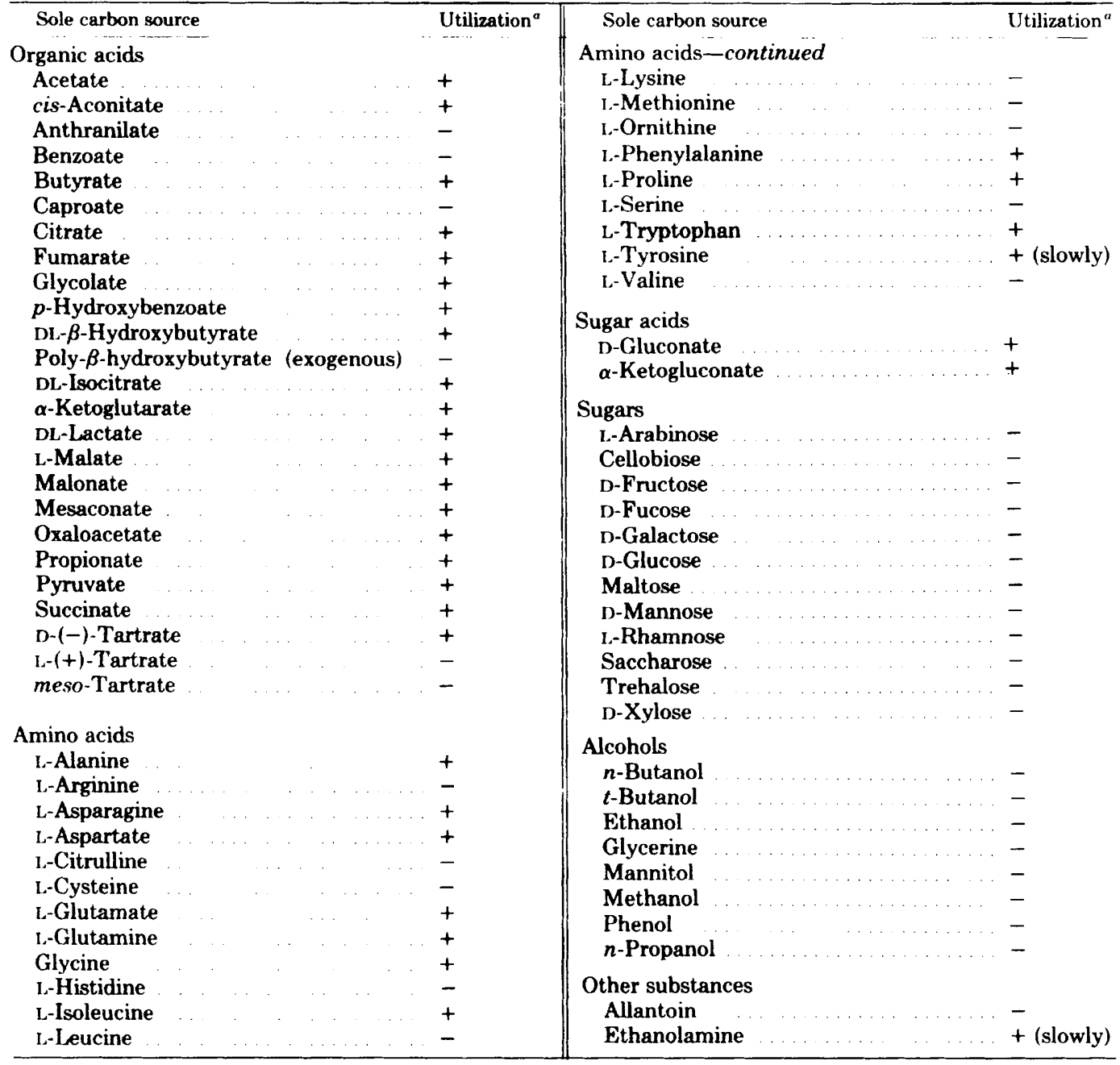

${ }^{a}+$, Utilized; - , not utilized.

of various compounds as sole carbon sources are summarized in Table 2; 72 compounds were tested, and $\mathrm{NH}_{4} \mathrm{Cl}$ was the nitrogen source. Among the compounds utilized were two sugar acids, 20 of 26 organic acids, and 11 of 21 amino acids. No growth occurred with sugars or alcohols. The best growth rates were obtained with succinate (generation time, $1.9 \mathrm{~h}$ ), L-malate, and D-gluconate (generation time, $2.0 \mathrm{~h}$ ). Ammonium salts, nitrates, asparagine, and urea were used as sole nitrogen sources, either for autotrophic growth or for growth with $0.1 \%$ succinate.

Autotrophic growth was microaerophilic. At low cell concentrations, the optimal oxygen concentration in the gas mixture was about $3 \%$, corresponding to about $1 \mathrm{mg}$ of dissolved oxygen per liter. A generation time of $4 \mathrm{~h}$ was obtained under autotrophic conditions in a 10-liter Biostat fermentor (Braun, Melsungen), with adaptation of the oxygen supply to increasing cell concentration. $\mathrm{CO}_{2}$ was fixed through the Calvin cycle; hydrogenase and ribulose diphosphate carboxylase were entirely inducible under autotrophic conditions; they were not detectable in heterotrophic cells grown in air (M. Aragno and H. G. Schlegel, in preparation). The hydrogenase was membrane bound only, and it failed to reduce either nicotinamide adenine dinucleotide or nicotinamide adenine dinucleotide phosphate.

The $\mathrm{G}+\mathrm{C}$ content of the DNA was $61.7 \mathrm{~mol} \%$ for strain SA 32 and $60.2 \mathrm{~mol} \%$ for strain SA 
33. The results of the DNA hybridization tests between these two strains and Aquaspirillum dispar strains are given in Table 3.

\section{DISCUSSION}

Apart from $\mathrm{H}_{2}$ autotrophy, the other characteristics of strains SA 32 and SA 33, as well as their habitat, fit with the description of the genus Aquaspirillum as defined by Hylemon et al. (8). Since $\mathrm{H}_{2}$ autotrophy is widespread among various bacteria, it is not a useful criterion for separation of taxa at the generic level.

However, there are distinct differences between strains SA 32 and SA 33 and other medium-sized spirilla (Table 4). These differences lie in a combination of features rather than in single unique features, although a number of

TABLE 3. DNA-DNA hybridization between the "hydrogen spirillum" and Aquaspirillum dispar strains

\begin{tabular}{|c|c|c|}
\hline \multirow[t]{2}{*}{ Source of DNA } & \multicolumn{2}{|c|}{$\begin{array}{l}\text { Degree of DNA } \\
\text { binding }{ }^{a} \text { with } \\
\text { strain: }\end{array}$} \\
\hline & SA 32 & $\begin{array}{c}\text { ATCC } \\
27510\end{array}$ \\
\hline SA 32 & 100 & 28 \\
\hline SA 33 & 78 & $\mathrm{ND}^{b}$ \\
\hline Aquaspirillum dispar ATCC 27510 & 28 & 100 \\
\hline A. dispar ATCC 27650 & 8 & 106 \\
\hline
\end{tabular}

unique features such as $\mathrm{H}_{2}$ autotrophy and utilization of $\mathrm{D}$-tartrate, $p$-hydroxybenzoate, tryptophan, and glycine do exist in these organisms. A dendrogrammatic plot of the relationships between the hydrogen spirilla and the other medium-sized spirilla, drawn from a similarity matrix (Jaccard coefficient) of data from Hylemon et al. (8), Kropinski (9), and the present work, is shown in Fig. 2. The separation between autotrophic spirilla and the other spirilla occurs at a level similar to that of other species between themselves. Furthermore, DNA-DNA hybridization assays between the hydrogen spirilla and Aquaspirillum dispar (previously thought to resemble the former) show only few, if any, similarities between the two organisms. Thus, we believe that the hydrogen spirilla represent a new species, for which we propose the name

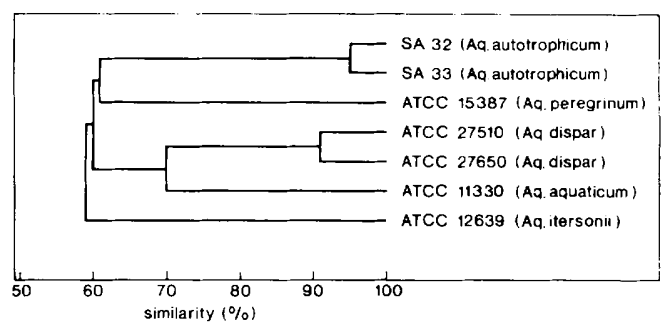

FIG. 2. Dendrogram showing the arrangement of medium-sized strains of Aquaspirillum after singlelinkage clustering. Similarities were determined using the Jaccard coefficient $S_{J}$.

TABLE 4. Characters useful in differentiating between strains $S A 32$ and $S A 33$ and other medium-sized aquaspirilla

\begin{tabular}{|c|c|c|c|c|c|}
\hline Character & $\begin{array}{c}\text { SA } 32 \text { and SA } \\
33\end{array}$ & A. dispar & A. aquaticum & A. itersonii & A. peregrinum \\
\hline Coccoid bodies in 3-week-old cultures & - & - & - & + & + \\
\hline Nitrate reduction $\ldots \ldots \ldots \ldots \ldots$ & - & $+\left(\mathrm{N}_{2}\right)^{\alpha}$ & $+\left(\mathrm{NO}_{2}{ }^{-}\right)$ & $+\left(\mathrm{N}_{2}\right)$ & - \\
\hline Anaerobic growth with nitrate as acceptor & - & $t^{\alpha}$ & - & + & - \\
\hline Water-soluble pigment $\ldots \ldots \ldots \ldots \ldots \ldots$ & - & + & + & + & + \\
\hline Sulfide from cysteine $\ldots \ldots \ldots \ldots \ldots \ldots$ & - & + & + & + & + \\
\hline$\ldots \ldots \ldots \ldots \ldots$ & + & - & - & - & + \\
\hline$\ldots \ldots \ldots \ldots \ldots$ & - & - & - & + & + \\
\hline Acid from carbohydrates $\ldots \ldots \ldots \ldots \ldots$ & - & - & - & + & + \\
\hline Selenite reduction $\ldots \ldots \ldots \ldots \ldots \ldots$ & - & + & + & - & + \\
\hline Growth with $1 \%$ glycine $\ldots \ldots \ldots \ldots \ldots$ & - & + & + & - & - \\
\hline Auxotrophy $\ldots \ldots \ldots \ldots \ldots \ldots \ldots \ldots \ldots \ldots$ & - & - & + & - & - \\
\hline \multicolumn{6}{|l|}{ Sole-carbon-source utilization } \\
\hline Gluconate $\ldots \ldots \ldots \ldots \ldots \ldots \ldots$ & + & - & + & - & - \\
\hline Citrate $\ldots \ldots \ldots \ldots \ldots \ldots$ & + & + & + & - & - \\
\hline$\ldots \ldots \ldots \ldots \ldots \ldots$ & + & - & - & - & - \\
\hline Caproate $\ldots \ldots \ldots \ldots \ldots \ldots \ldots$ & - & + & + & - & - \\
\hline$p$-Hydroxybenzoate $\ldots \ldots \ldots$ & + & - & - & - & - \\
\hline Glycine $\ldots \ldots \ldots \ldots \ldots \ldots \ldots \ldots \ldots \ldots \ldots$ & + & - & - & - & - \\
\hline Tryptophan $\ldots \ldots \ldots \ldots \ldots \ldots \ldots$ & + & - & - & - & - \\
\hline Ethanol $\ldots \ldots \ldots \ldots \ldots \ldots \ldots$ & - & + & - & + & - \\
\hline $\mathrm{NO}_{3}{ }^{-}$as sole $\mathrm{N}$ source & + & - & + & + & - \\
\hline $\mathrm{Mol} \% \mathrm{G}+\mathrm{C}$ of DNA & $60-62$ & $63-65$ & 65 & 62 & 62 \\
\hline
\end{tabular}

${ }^{a}$ These features differ from those given by Hylemon et al. (8), but we have verified that $A$. dispar is a denitrifier and grows vigorously anaerobically with nitrate as the electron acceptor, producing gaseous nitrogen. 
Aquaspirillum autotrophicum. A description of this species follows.

Aquaspirillum autotrophicum sp. nov. (au.to.tro'phi.cum. Gr. pronoun autos self; Gr. adj. trophikos nursing, tending, or feeding; M.L. adj. autotrophicus self-nursing or self-feeding, i.e., able to grow with carbon dioxide as a sole carbon source).

Curved to spiral cells, 0.6 to $0.8 \mu \mathrm{m}$ wide, 2 to $5 \mu \mathrm{m}$ long (older cells may be up to 50 ); the wavelength is 3 to $4 \mu \mathrm{m}$; the helix is oriented in a clockwise fashion. Gram-negative. Motile by means of bipolar fascicles of one to five flagella. Intracytoplasmic granules of poly- $\beta$-hydroxybutyrate are present. No coccoid bodies occur in older cultures. Temperature for optimal growth: $28^{\circ} \mathrm{C}$; slight growth occurs at 10 and at $35^{\circ} \mathrm{C}$. Either chemolithoautotrophic, using $\mathrm{H}_{2}$ as the electron donor and $\mathrm{CO}_{2}$ as the carbon source, or chemoorganoheterotrophic; strictly respiratory metabolism, with oxygen as the terminal electron acceptor. Cannot grow anaerobically with nitrate. Hydrogenase is induced by molecular hydrogen, is membrane bound, and is not nicotinamide adenine dinucleotide specific. $\mathrm{CO}_{2}$ is fixed autotrophically through the Calvin cycle. Catalase, phosphatase, and urease are positive. Sulfatase is not produced. $p$-Hydroxybutyrate is metabolized via the ortho cleavage of protocatechuate. Does not hydrolyze starch, casein, gelatin, esculin, or extracellular poly- $\beta$-hydroxybutyrate. No acid is produced from sugars. Selenite is not reduced. $\mathrm{H}_{2} \mathrm{~S}$ is not produced from cysteine. Grows in the presence of $1 \%$ bile salts. No growth occurs in the presence of either $1 \%$ glycine or $3 \% \mathrm{NaCl}$. Water-soluble fluorescent pigment is not produced. Nitrate is reduced but only for assimilation. A wide range of organic acids, amino acids, and sugar acids can serve as sole carbon sources with ammonium ions as a nitrogen source. Sugars and alcohols are not metabolized. Ammonium ions, nitrates, urea, and asparagine can be utilized as sole nitrogen sources. The $\mathrm{G}+\mathrm{C}$ content of the DNA is 60 to $62 \mathrm{~mol} \%\left(T_{m}\right)$.

Source: Isolated from the water of a small eutrophic lake near Neuchâtel, Switzerland.

Type strain: Strain SA 32 is designated as the type strain for the species. It has been deposited with the Deutsche Sammlung von Mikroorganismen under the number DSM 732. The description of the type strain is the same as that given above for the species, with the following addition: the $\mathrm{G}+\mathrm{C}$ content of the DNA is $61.7 \mathrm{~mol} \%$ $\left(T_{m}\right)$.

\section{ACKNOWLEDGMENTS}

We are grateful to Michael Reh, Institut für Mikrobiologie der Universitat Gottingen, who made the DNA base composition determinations and hybridizations, to Noel R. Krieg,
Virginia Polytechnic Institute and State University, Blacksburg, Va., for valuable discussion and encouragement, and to Joan Macy, who kindly revised the manuscript.

One of us (M.A.) benefited from a leave from the University of Neuchatel (Switzerland) and from a grant from the Department of Public Education of the canton Neuchatel.

\section{REPRINT REQUESTS}

Address reprint requests to: Prof. Dr. H. G. Schlegel, Department of Bacterial Physiology, Institut für Mikrobiologie der Universität Göttingen, Grisebachstr. 8, 3400 Göttingen, Federal Republic of Germany.

\section{LTTERATURE CITED}

1. Aggag, M., and H. G. Schlegel. 1973. Studies on a Gram-positive hydrogen bacterium, Nocardia opaca strain lb. I. Description and physiological characterization. Arch. Mikrobiol. 88:299-318.

2. Baumgarten, J., M. Reh, and H. G. Schlegel. 1974. Taxonomic studies on some Gram-positive coryneform hydrogen bacteria. Arch. Microbiol. 100:207-217.

3. Davis, D. H., R. Y. Stanier, M. Doudoroff, and $M$. Mandel. 1969. Proposal to reject the genus Hydrogenomonas, taxonomic implications. Int. J. Syst. Bacteriol. 19:375-390.

4. Davis, D. H., R. Y. Stanier, M. Doudoroff, and $M$. Mandel. 1970. Taxonomic studies on some Gram-negative polarly flagellated "hydrogen bacteria" and related species. Arch. Mikrobiol. 70:1-13.

5. Deley, J., H. Cattair, and A. Reynaerts. 1970. The quantitative measurement of DNA hybridization from renaturation rates. Eur. J. Biochem. 12:133-142.

6. Hirsch, P. 1961. Wasserstoffaktivierung und Chemoau totrophie bei Actinomyceten. Arch. Mikrobiol. 29:360-373.

7. Holding, A. J., and J. G. Collee. 1971. Routine biochemical tests, p. 12. In J. R. Norris and D. W. Ribbons (ed.), Methods of microbiology, vol. 6A. Academic Press Inc., London.

8. Hylemon, P. B., J. S. Wells, Jr., N. R. Krieg, and H. W. Jannasch. 1973. The genus Spirillum: a taxonomic study. Int. J. Syst. Bacteriol. 23:340-380.

9. Kropinski, A. M. 1975. A chemically defined medium for Aquaspirillum aquaticum ATCC 11330. Can. J. Microbiol. 21:1886-1889.

10. Lukins, H. B., and J. W. Foster. 1963. Utilization of hydrocarbons and hydrogen by mycobacteria. Z. Allg. Mikrobiol. 3:251-254.

11. Mandel, M., and J. Marmur. 1968. Use of ultraviolet absorbance-temperature profile for determining the guanine plus cytosine content of DNA. Methods Enzymol. 12B: 195-206.

12. Park, S. S., and B. T. DeCicco. 1974. Autotrophic growth with hydrogen of Mycobacterium gordonae and another scotochromogenic Mycobacterium. Int. J. Syst. Bacteriol. 24:338-345.

13. Pfennig, N., and K. D. Lippert. 1966. Über das Vitamin$\mathrm{B}_{12}$-Bedürfnis phototropher Schwefelbakterien. Arch. Mikrobiol. 55:245-256.

14. Schlegel, H. G. 1975. Mechanisms of chemo-autotrophy p. 9-60. In O. Kinne (ed.), Marine ecology, vol. 2. Wiley \& Sons, London.

15. Schlegel, H. G., H. Kaltwasser, and G. Gottschalk. 1961. Ein Submersverfahren zur Kultur wasserstoffox ydierender Bakterien: Wachstumsphysiologische Untersuchungen. Arch. Mikrobiol. 38:209-222.

16. Schweizer, C., and M. Aragno. 1975. Etude des hydrogénobactéries dans un petit lac (le Loclat, ou lac de Saint-Blaise). Bull. Soc. Neuchatel. Sci. Nat. 98:79-87.

17. Stanier, R. Y., N. J. Palleroni, and M. Doudorofi. 1966. The aerobic pseudomonads: a taxonomic study. J. Bacteriol. 87:293-302. 